\title{
建築のエネルギー効率政策に関する OECD 諸国の国際比較 INTERNATIONAL COMPARISON CONCERNING BUILDING-RELATED ENERGY EFFICIENCY POLICY IN OECD COUNTRIES
}

\author{
安藤尚 -* \\ Shoichi ANDO
}

\begin{abstract}
This study is based on the OECD survey on sustainable building policy in July 1999. 45 energy policies and 54 energy-related policies from 16 countries and EU are analyzed in detail. Building sector is responsible for one third of total energy consumption and $\mathrm{CO}_{2}$ emissions. This study highlights advanced policy examples and tries to identify significant measures and main barriers for energy efficiency and $\mathrm{CO}_{2}$ reduction policy in the building sector. Finally, some comments and proposals on Japanese relevant policy are described, so as to overcome Japanese difficult situation where the $\mathrm{CO}_{2}$ emission is growing rapidly in spite of severe Kyoto target.
\end{abstract}

\section{Keywords : Sustainable building, Energy efficiency policy, Energy Conservation, Climate change (Global warming), Building policy, International comparison サステナブル建築、エネルギー効率政策、省エネルギー、気候変動（温暖化防止）、建築政策、国際比較}

\section{1. はじめに}

建築物には、地球環境問題の視点からエネルギーの㹢率的利用、 温暖化ガスの排出削減が強く求められてきている。これらの取組み は、先進国共通の建築政策の重要な課題となってきている。

本論では、これらの課題に政策面からどう取組むべきかを国際的 な梘点で分析し、先進国でとられている政策を比較分析した。本研 究は、経済協力開発機棈（ＯＥＣＤ）で実施中のサステナブル建築 プロジェクトの調査結果を基礎としている。このプロジェクトは、 O E C D諸国が行っているエネルギー施策を含む建案物に係る環境 政策を把握・分析し、各国の実情に適した政策メニューを提案する 事業であり、筆者が担当している。本論は、OECDで筆者が行っ た分析に、さらに詳細な考察を加えたものである。

本論の目的は、建筑政策の視点から各国のエネネルギー政策、温暖 化防止対策を比較検郡し、建築のエネルギー効率政策の特徽を把握 するとともに、日本の政策手段を国際的に評価することである。

\section{2. 各国のエネルギー使用の現状と踝題}

（1）OE C D諸国のエネルギー消费と温暖化ガス排出の現状 OE C D諸国の全エネルギー消費の約 3 割が、建築や住宅部門を
中心とするその他部門である。これは国によって 1 割程度異なる。

温暖化ガスの大部分を占める二酸化炭素の排出は、火力発電所を 中心とする電力部門の割合が大きい。しかし、電力の約半分を照明 や暖営など建築物内部で消費していることを考虑すれば、エネルギ 一消費とほぼ同じ約 3割を建築住宅部門が占めている。1)

\section{（2）省エネ・温暖化ガス削減対策の経䋖}

エネルギーの効率的利用及び使用削堿（省エネ）は、1970年 代の 2 回にわたるオイルショック以降、先進各国で真剣に取組まれ てきている。日本では1979年に「エネルギー使用の合理化に関 する法律（省エネ法）」が制定され、その基準が次第に強化されて きた。国際的には1974年に国際エネルギー機関（IＥＡ）がO P E C 産油国のカルテルに対抗して、省エネと石油備蕃を先進国で 共同して進めるためにOE C D と同じ加盟国で設立されている。

1990 年代に入り地球温暖化防止が国際社会の大きなテーマに なってくると、ェネルキーの有効利用が経済問題としてよりも㻴境 問題として再び脚光を浴びてきている。特に、1997年12月の 気候変動枠組条約第 3 回締約国会議（COP 3 ）で京都議定書がま とまると、そこに盛られた 2010 年時の目標達成が、OE D D 各 国政府の重要な政策課題になっでさいる。(表 1)

\footnotetext{
* 経済協力開発機構 $(\mathrm{OECD})$ ，環境局污染防止管理課 管理官 Principal Administrator, Pollution Prevention and Control Division, Environment Directorate, Organization for Economic Co-operation and Development (OECD)
} 


\begin{tabular}{|c|c|c|c|}
\hline \multicolumn{4}{|c|}{$\begin{array}{l}\text { 表 } 1 \text { OE CD加盟各国の温䁔化ガス排出状況と京都会䂀の目標 } \\
E U \text { 域外 }\end{array}$} \\
\hline (ABC 順) 90 年 & 量 $\left(\mathrm{Mt}-\mathrm{CO}_{2}\right)$ & 95/90 京 & 票(2010/1990 \\
\hline オーストラリア & 406 & $6 \%$ & $8.0 \%$ \\
\hline カナダ & & $10 \%$ & -6 . \\
\hline チェコ & & $-21 \%$ & -8 \\
\hline ハンガリー & 102 & $-24 \%$ & -6 \\
\hline アイスランド & 3 & $5 \%$ & 10. \\
\hline 日本 & 1190 & $8 \%$ & $-6.0 \%$ \\
\hline ニュージーランド & 76 & $0 \%$ & $0.0 \%$ \\
\hline ノルウェイ & 49 & $6 \%$ & 1. $0 \%$ \\
\hline ポーランド & 564 & $-22 \%$ & $-6.0 \%$ \\
\hline スイス & 54 & $-2 \%$ & $-8.0 \%$ \\
\hline 米国 & 5713 & $5 \%$ & $-7.0 \%$ \\
\hline
\end{tabular}

$E U$ 踫国 (EU 全体の目標は-8.0\%で、EU内で各国に配分) （ABC 順） 90 年排出量(Mt-CO2) $95 / 90$ 京都目標(2010/1990) オーストリア 78

$\begin{array}{llll}\text { ベルギー } & 139 & 6 \% & -7.5 \%\end{array}$

デンマーク

フィンランド

フランス

ドイッ

ギリシア

アイルランド

イタリア

ルクセンブルグ

オランダ

ポルトガル

スペイン

スウェーデン

英国

72

$10 \%$

$3 \%$

$0 \%$

498

1204

99

57

532

13

207

68

301

65

715

$-12 \%$

$6 \%$

$4 \%$

$2 \%$

$-24 \%$

$8 \%$

$6 \%$

$2 \%$

$3 \%$

$-9 \%$

$-21.0 \%$

0. $0 \%$

0. $0 \%$

$-21.0 \%$

$25.0 \%$

13 . $0 \%$

$-6.5 \%$

$-28.0 \%$

$-6.0 \%$

$27.0 \%$

$15.0 \%$

4. $0 \%$

$-12.5 \%$

OECD 加盟国の内、韓国、トルコ、メキシコを除く 26 ヶ国2)

\section{（3）エネルギー政策と温暖化防止対策に占める建築の割合}

現在のOE C D諸国におけるエネルギー政策は、従来のエネルギ 一安定供給対策から、電力業界を中心方市場原理の導入（自由 化）と、温暖化防止が大きな柱となってきている。温暖化防止対策 は各国政府の中で、環境省が総合的な政策を実施しているものの、 エネルギー政策の中で最も真剣に取組まれている。これは、二酸化 炭素の直接の排出は、産業部門、交通部門、民生部門以上に、電力 部門がその責任を負っているためである。

ここて、I E A の国別エネルギー政策レビューから、エネルギー 政策や温暖化防止対策に占める建築部門の割合を見ると、以下のよ うな事例が挙(千られる。3)

\section{表 2 先進各国のエネルギー政策に占める建筑分野の割合（例）}

（米国）温暖化防止行動計画：全 $169 \mathrm{Mtce}$ (石炭換算百万卜 ン) の温暖化ガス排出削減目標のうち、建築住宅部門が $53 \mathrm{Mtce}$ (全体の $31 \%$ )。うち $36 \mathrm{Mtce}$ が全エネルギースター計画。

（英国）温暖化防止対策による $\mathrm{CO}_{2}$ 削減勃果 : 年間で全 $35 \mathrm{Mtc}$ (炭素換算百万トン) のうち電力部門 $22 \mathrm{Mtc、}$ 、交通部門 $3 \mathrm{Mtc}$ 、 産業・商業部門 $8 \mathrm{Mtc}$ 、住宅部門 $2 \mathrm{Mtc}$ (商業を含め $29 \%$ )。

(ヘルギー) $\mathrm{CO}_{2}$ 排出削減国家計画： $\mathrm{CO}_{2}$ 換算で全 $7.7 \mathrm{Mt}$ （百万トン）のうち、産業部門 2.8 $8 \mathrm{Mt}$ 、交通部門 $1.7 \mathrm{Mt}$ 、 住宅・建築部門 $3.2 \mathrm{Mt}$ (全体の $45 \%$ )。

（カナダ）省エネ、代替エネに関する連邦政拊支出 1995 年： 全 $58 \mathrm{MC}$ （百万カナダドル）のうち、産業部門 $15 \mathrm{MC} \$$ 、交 通部門 $10 \mathrm{MC}$ 、建築住宅部門 $18 \mathrm{MC}$ (全体の31\%)、他。
表 2 の下線部のデータを総括すると、省エネ政策や温暖化防止 対策における建築部門は、交通部門や座業部門に劣らす、OE C D 諸国に代表される先進国で大きな割合を占めている。

これは、建築部門のエネルギー消費や温暖化ガス排出量が大きい ことが基本的な要因である。さらに、産業部門での省エネ対策は既 に相当進んでいること、産業界の器境対策は経済的に見合うように なってきており政府の支援は不要になってきたこと、交通部門では 自動車産業など大企業が環焼技術の開発競争をしていることなどと 対照的に、建築部門では、理境技術の開発や適用をボランタリーな 努力に頼っており、設計者、施工者、管理者や行政の省エネに対す る理解不足、施主や利用者が環境対策を講じる動機が少ないことな どから、政府による規制や支援が必要なことが主な要因である。

\section{3. 各国の具体的政策}

\section{（1）建策部門の理境対策の制度テータ}

OECDが1999年 7 月までに加盟 16 国とEUから収集した 建筑部門の環境対策に関する制度面のデータは、合計 172 制度に 及ぶ。これを政策分野別に見ると図 1、さらに政策分野每に政策手 法別に見ると図 2 の通りである。本論ではこれらの中からェネル ギー関保の制度データをもとに以下の分析を試みている。4)

ここで特に図 2 から、エネルギー対策が他の環境政策分野と比較 して、1，経済的手法と複合的手法が多く使われており、2．規制 手法と自主的手法が比較的少ない点（5．参照）が注目される。

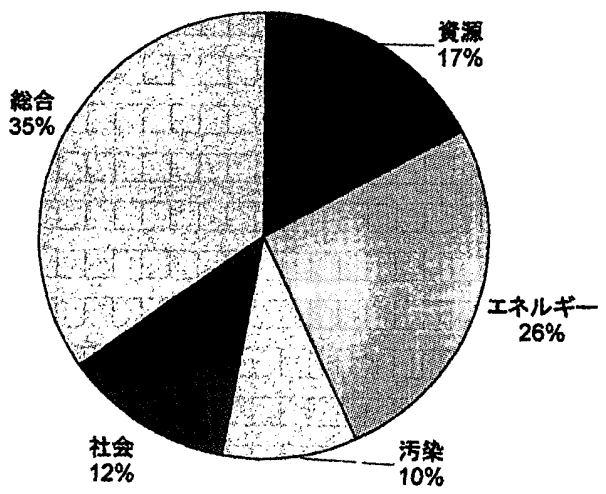

図 1 サステナブル建築政策 172 事例の政策分野割合

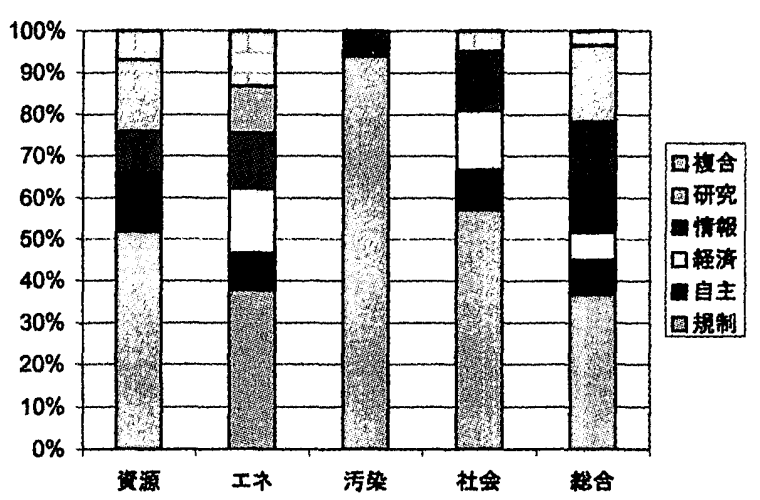

図 2 サステナブル建築政策 分野別の政策手法割合 


\section{（2）省エネに開する建築政策の具体例}

前述のOECDデータでは、エネルギー関係が.45 制度、エネルギ 一や資源、污染防止などを総合的に取組む制度が 54 ある。この 54 制度の大部分にエネルギー関連の項目が入っていることから、OE C $\mathrm{D}$ 調查の 172 制度で見ると、世界的に建筧部門の環境対策の半数以 上はエネルギーに関係しているといえる。

また、この 45 のエネルギー関係政策のうち、温暖化防止に関する

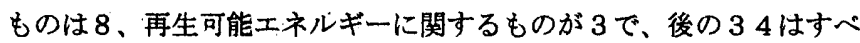
て省エネ対策である。さらに、34 ある建築部門の省エネ対策に関す ろOECD各国の制度を、規制、自主、経済、情報、技術の5つの政 策手法別に見ると、以下のような制度が注目される。

\section{表 3 省エネ政策の真体例 （政策手法別）}

\section{(规制政策) 13 制度}

・多くの国で制定されている断熱材に関する規則に加え、フィンラ ンドやドイツで制定されている熱供給設備に関する規則

(自主政策) 2 制度

・オランダ、オーストラリアでの産業界や国民が主導の自主活動

(経済政策) 5 制度

・カナダ、日本、米国での省エネ建築に対する経済支援制度

・オランダの環境税（エコタックス）

(情報政策) 6 制度

-カナダのRー2000住宅による省工ネ住宅技術の普及・訓練

・オランダのエネルギー性能認定制度、ギリシアのエコエネルギー ラベル、スイスのミネギーラベル、米国のエネルギースターラベ ルといった建築部門を含むエネルギー効率表示制度

（技郝政策） 4 制度

・オーストラリア、カナダ、スイスでの高度な省エネ技術の開発普 及を目指した研究

(裨合政策). 4 制度 (上記政策の組合せ).

・ギリシア（エネルギー2001）とEUの総合省エネ計画

・米国のエネルギースター計画（ラベル、経済支援などを含む。）

\section{（3）再生可能エネルギー（新エネルギー）利用に関する政策}

新エネルギーとは、化石然料や原子力以外の新しいエネルギー源と して開発されたもので、風力や太陽光による発電、地熱、潮力などの 再生可能エネルギーに加え、下水廃熱利用やゴミ発電、コージェネレ ーション、然料電池などが含まれている。従来からある再生可能エネ ルギーとしては、木材などの生物資源と水力発電がある。

建築において、この再生可能エネルギ一・新エネルギーの利用を促 進している仕組みとして、1 72 制度の中に次の 3 事例がある。

（カナダ）再生可能エネルギー展開率先行動（天然資源省）

（キリシア）再生可能エネルギーの促進に関する基本法（開発省）

(スイス) ソーラー建築（連邦技術研究所、チューリッヒ）

再生可能エネルギーを巡る最大の課題は、経済性である。太陽光発 電や風力発電は実用化段階に来ているとはいえ、より安価で効率の良 い技術の開発と電力会社による安定的な余剩電力の項取りが、今後の 普及の鍵を握っている。

\section{（4）温暖化防止に関する建築政策の具体例}

OE CDの調查で 8つ挙げられた地球温暖化防止対策のうち 3 つは オーストラリア環境省の温暖化防止計画に関するものである。このう ち、家庭温暖化防止行動と温暧化防止チャレンジ計画は、それぞれ家 庭部門と産業部門を対象にした政府との共同計画である。政府は京都 目標の達成がこのような自主計画だけでは危ぶまれる場合、建築基準
のなかに強制的な温暧化防止策を盛込むことを計画している。これは 1997 年 1 1.月に同国の首相が 1.8 譩索ドルの温暧化防止策を発表 した際に述べられている。

これに対して、日本では1998年に努力規定として地球温暖化対 策の推進に関する法律を制定した。また、併せて住宅分野で 1999 年に省エネルギー基淮を強化している。このように政府主導、場合に よっては規制を導入して、建案の温暖化対策を進めようという動きは、 ギリシア政府の決定や、EUの建築のエネルギー奻率を通じた $\mathrm{CO}_{2}$ 排出の安定化に関する指令（SAVE）でも共通している。なお、キ リ.シア政府の決定はEUの指令をもとにしている。

経済的手段を建築部門の温暖化防止対策に導入している例としては、 カナダ天然凟源省の主導により地方公共団体や公益機関が中心となっ たエネルギー改革率先行動が挙げられる。

\section{（5）薪境に関する總合的な建筑政策}

OE CD各国の具体的政策の最後に、総合的な 54 制度について分 析を試みた。まず、各国の代表的な総合的政策において、省エネや温 暖化防止がどの程度の割合を占めているかを分析した。ここでは、代 表例としてオーストラリア連邦科学産業研究所の生態的サステナブル デザイン（E S D）実証建築、カナダのグリーン・ビルディング・チ ヤレンジ（GBC）９8、日本の建設省のグリーン庁舎（GGB）、 オランダのサステナフル建築による国家総合事業（NPSB）、スイ スのライフサイクルにわたる環境影警計算プログラム（OG I P) と 英国の建築研究・革新業務計画（C R I ）を取り上げた。各制度の対 象項目の概要は以下の通りである。

\section{表 4. 建筮に関する維合的な政策の項目（下線はエネルギー関俰）}

（E S D） 33\%の省エネ、低水淮の製造エネルギー（ embodied energy)、改修リサイクルの容易性、良好な室内空気質、(大気、水) 環境への影帮最少、（太陽、風雨など）天然资源の有効利用、（景 観、交通など）周辺棵境との調和の 7 大項目

（G B C）資源（エネルギーを含さ）消費、環境負荷、室内環境 の買、長期耐用性、プロセス（ライフサイクル管理）、近隣環境要 因の6大項目（全19中項目、80小項目）

（GＧＢ）周辺環境への配虑、運用段階の省エネ・省資源、長寿命 化、エコマテリアルの使用、適正使用・(廃雍物) 適正処理の 5 大 項目（省エネで3中項目、全 26 小項目）

（N P S B ）デザイン及び配膡に関する手法、技術手法及び実施段 階で樓じるべき手法の 2 大項目（全３７中項目、160 小項目）

（OGＩＰ）コスト、エネルギー、環境（温䐘化ガス排出）の3 要 素（この関俰をライフサイクル全般にわたうて計算する仕組み）

（C R I）サステナブル建設 B P (業務計画 )、建築内の安全と健 康 B P 、技術と性能 B P、建設プロセス B P、ベストプラクティス BPの 5 大項目（各々 4 項目に細分化）

次に、これらの政策に共通する特徽を以下に列举する。

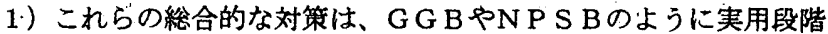
のものから、ESDのように研究段階のものまであるが、いず れも制度の創設から数年という新施策である。

2）環境に配慮した建築の総合的な政策では、省エネ（と温暖化カ スの排出抑制）が程度の差こそあれ必ず取り上げら机ており、 
項目数では 6 分の 1 から 3 分の 1 程度を占めている。

3）近年は、温暖化ガス排出の抑制が罢境に関する総合的な建築政 策全体の中で占める比重が高まる傾向にある。( 特に 1997 年 12 月の京都会識以降の施策、例: OG I P、G B C )

4) 省エネや温暖化ガス削减の項目では、自然との調和や资源有勃 利用に比㜞して目標が具体的に設定しやすい。（特に使用量が 容易に把握できる運用段階での数值指標）

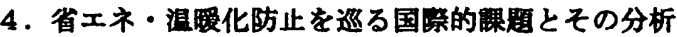

最近の省エネの課題を国際的に見ると、1．省エネ意欲の減退、 2. 政策立案機関の連㩲不足、3. 温暖化ガス削減の㗨急性の国に よる相違などが、各国に共通する神瑱として指摘できる。

第一の課題として、原油価格が高騰している時期には、経済的な 要因から省エネが進めやすいが、現在のように価格が低迷している 時には、省エネや太陽光などの代替エネルギーの利用は進みにくい ことが挙げられる。しかし、気候変動枠組条約の制約及びEMAS やISO14000シリーズをはじめとする環境管理に関する自主 的な取組みの浸透から、原油価格に関係なくエネルギー効率を高め る動きが見られる。このことは更に原油価格を引き下げる要因とも なっており、石油輸出国や米国の石油産業にも蛬造転換を迫ってい る現状がある。しかし、エネルギー価格の低迷は、安価な化石燃料 に対して炭素税などの璒境税を課すことにより、温暖化防止を政策 的にコントロールする余地を生んでいることにもなる。

ここで、建勧部門について見ると、エネルギー価格に対する助成 を行う場合には、今後の電力自由化の動きや国際的な価格差をにら んで政策を決定する必要がある。例えば、今後日本の電力・エネル ギー価格（図3）が国際水準に近つくならば、太陽光や風力による 発電コストの採算点も下方修正する必要が出て来よう。

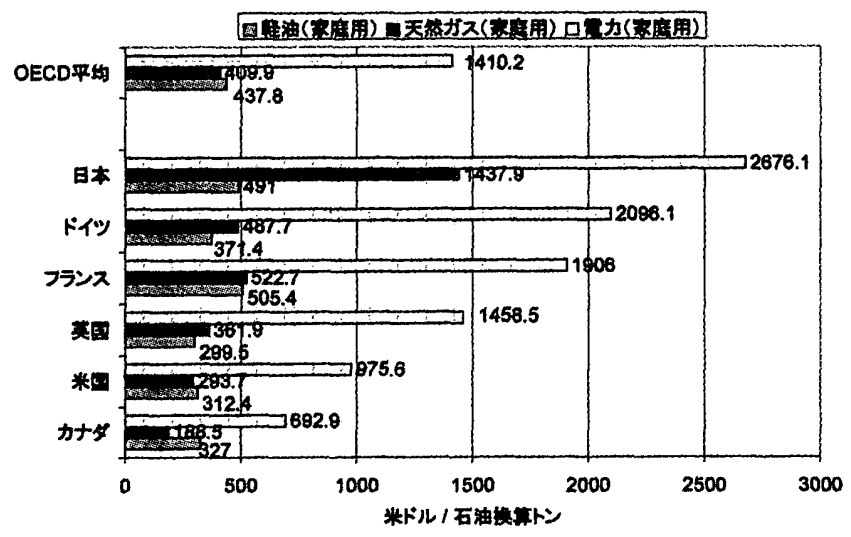

图 3 OE C D諸国の家庭用エネルギー価格の国際比較 ${ }^{5)}$

第二の課題である政策担当部局間の連挜については、エネルキー 政策部局は、多くの国で圱業政策と一緒の省庁となっており、建策 や住宅政策部局と同じ省庁であることはまずない。ただし、英国や オーストラリアなど、建設産業の担当部局がエネルギー部局と同じ 省庁の場合があり、法制度面や予算面で比較的充実した建築部門で の省エネ対策が取られている。もちろん、カナダやスイスのように 担当省庁は異なっていても、問題の重要性を双方の担当部呞が理解 して、連携を比較的うまく図っている国もある。
エネルギー政策と璄境政策又は建筑政策の両方が分かる政策立案 者は世界中を見てもほとんどいないといわれている。この3つの政 策は同じエネルギー效率を扱うにしても、それぞれ根拠となる䘽点 がかなり違う。エネルギー政策はエネルギーの安定供給、環境政策 はエネルギー资源が原因となる環境污染防止、建勧政策はエネルギ 一利用による安全で快適な室内䀼境の確保を、各々目的としている ため、政策体系も担当官庁も違うことが多いからである。

三番目に、温暖化ガスの削減目標の相量（表 1）や、エネルギー 転換政策や経済状況などにより、国によって建築部門に求められる 省エネの程度が異なっている。欧州では建築住宅部門での温暖化ガ ス削減については、北米や日本ほど梁刻には受け取られていない。 (欧州では交通部門の温暖化防止対策が最も大きな課題である。)

\section{5. 建策のエネルキー効新政策の分析と眯题}

\section{（1）政策の分類}

建築部門の瑠境対策を政策手法で大別し、手法別にそれぞれ代表 的な制度手法を記すと以下のようになる。

1）規制政策 （法律、規則、決定、強制的な規灌、基淮など）

2) 自主政策 (ボランタリー計画、率先計画、共同行動など)

3）経済政策（税制、補助、殿資、課徽金、排出権取引など）

4）情報政策 （ラベル、教育、影製評価、モデル事業など）

5）技術政策（研究、技術開発、技術普及など）

6）複合政策 （上記 1）から5）の手法の組合わせ）

172 あるサステナブル建築政策のうち、45のエネルギー対策 を政策手法別に見ると、規制政策 17 、自主政策 4、経済政策 $7 、$ 情報政策 6 、技術政策 5 、上記の組合せ 6 の制度数である。ここで 規制が特に多いのは、OECDの調查項目の立て方によるものと解 される。実際にエネルギーと総合対策以外の資源、污染防止、社会 面での制度では、規制政策がそれ以外の政策手法に比べて多くなっ ており、エネルギー対策は規制政策の利用率が低い。（図 2 参照）

\section{（2）政策の分析 1 (規制政策の課周)}

ここで、建築のエネルギー効率政策、中でも省エネ対策の特徽と して、法规制が比較的少ない理由を分析してみた。

まず、石油危機を契機とした省エネ対策は、もともと経済問題と して扱われていた点が挙げられる。特に産業部門では、交通や建策 部門に比較して市場原理が妝きやすいため、1980年代中にエネ ルギー依存度は急速に下がっている。いずれの部門でも当初にはエ ネルギーの使用制限などの規制はなく、啓蒙普及、経済政策、技術 開発などの规制政策以外の政策が諥じられていた。

ただし建築部門では、コストの見えやすい建設段階のエネルギー コストはわずかであること、エネルギ一使用量の多い運用段階でも エネルギーコストをフローで見た場合には建築物の管理費や家計に 占める割合は小さいことから、市場原理が働きにくい㑯向がある。

次に、省エネをしない場合に生じる問題が、健康被害や社会的損 失に結びつかないと考えられていたことが挙げられる。しかしこの 点は、二酸化炭素排出削减という地球謤境対策と省エネが密接に結 びついたことから、省エネは個人的な経済問題から、国際的な公共 の利害に関る間題になったといえよう。

さらに、エネルギー使用の規制を講じてもその確認方法が確立さ れていない点が挙げられる。確認方法としては、公共が直接現場で 
又は書面で検査する場合と、資格者を設けて確認させる場合などが あるが、検查方法に関する技術のほかに、検查費用や検查体制の面 でも、勃率的な方法が磪立しないと規制の実効が上がらない。建築 の省エネ規制では、多くの国で建勧の許可と連動させている。この 場合は、検查を行う公共団体の技術力や体制が課題となっている。 また、本来は消防による防火管理のように運用段階での省エネ実績 の確認を行うべきであるが、公共による直接の確铝は困難である。

また、エネルギー産業が早くから育ち、政治的な力を持っている 国では、エネルギーの使用制限に関する法律が議会を通りにくい。

以上のような課题が規制政策にはあるが、産業部門が国際競争力 の点から省エネの限界に来ていたり、誘導的政策を十分に講じても まだ省エネを行う必要がある場合には、規制政策が採用される。

\section{（3）政策の分析 2（奻果的な政策手法）}

規制政策は、ある意味では最後の手段であり、その前に市場を歪 めない誘導的措掼や市場原理を活用した経済手法を十分講じる必要 がある。建筑のエネルギー効率政策においては、どのような政策が 効果的であろうか。第 3 章での政策例から以下の点が考察できる。

\section{(自主政策)}

1）自主政策は、業界や家庭での自主的取組みを支援する手法であ るが、その対象は市場原理だけでは進まない事項が多い。多く の埸合、自主政策は規制事項となるべき内容を中に含んでおり （例： $\mathrm{CO}_{2}$ 削減）、規制政策の前段階であるといえる。

2）そこで、自主政策を行う場合には、政策の効果が現れない時に は規制政策を導入する、と宣言しておくことが肝要である。

3）自主政策は、'政府側には経済的負担が少なく、業界との関係が 良好な場合には効率的な政策手法といえる。ただし、取組むべ き内容が、複雑だったり、レベルが高い場合には自主的な意欲 がそがれる点に注意し、可能であれば経済的なインセンティフ を同時に与えることが効果的である。

4）他の疅境対策で効果を発揮している自主政策の場合は、対象と なる施設が限られているが、建築物の場合は膨大な数になる。 そこで、政府が基準を作成したり、個別に势定を結ぶ場合は、 まず大型施設から始めることが効率的である。

\section{(䋃済政策)}

1）新たな税制の㓣設が困難である場合には、既存の税制を省エネ 誘導型に改革すること（グリーン化）をを検討する。その場合、 増税と減税が鲜り合うようにする。（日本の税制措圈では堿税 が多く、性格上は補助金に近いとされる。）

2）補助金は、(（OE C Dでは）市場原理を歪める場合が多いとさ れ、その対象や適用方法には注意が必要である。このため（財 政改革もあり)、環境面でマイナスに㗢いている補助金を削減 することが各国で検討されている。

3）他部門で多用されている、課徽金、排出権取引、預託金などの 市場原理を活用した政策を建筑部門でも検討する必要がある。

\section{（情報政策）}

1）新たな政策課題の場合や新しい制度への理解を消費者に深めて もらうため、まず啓蒙を主眼とした情報政策は重要である。

2）従来の広報やパンフレットなどの媒体に加え、インターネット の利用もあるが、ラベル制度は消費者の啓蒙に効果的である。 ただし、建築物へのラベルの適用については、耐用年数が極め
て長い点、用途変更、改築や維持管理への対忘が課題となる。

3）専門家に対する情報提供は、セミナーやシンポジウム、専門詰 などを通じて行うが、省エネや自然エネルギー利用の優良事例 やモデルプロ.ジェクトの紹介が効果的である。

\section{(技得政策)}

1）技術開発の成果を情報政策、経济政策、自主政策や規制に用い る場合は、建設業向けに普及型の技術や指針を作成する。

2) 将来的に大きな社会的課題になる事項（温暧化防止など）につ いては、基礎研究から政府が責任を持って行う必要がある。

3）省エネ基準などの政策的課題を研究する場合には、研究機関と 政府が密接な連係をとることが重要である。

\section{6.日本における政策の評価}

（1）エネルギーの有効利用に関する政策の辣価と提言 （規制政策の訣価）

まず、日本の規制システムの基本は、エネルギー使用の合理化 に関する法律（省エネ法）である。建築部門は産業部門と同じ法体 系となっており、建築政策とエネルギー政策との連携が取りやすく なっている。ただし、工場内のエネルギー管理に比して建築におけ る管理は遅れている。これは、ドイツやフィンランドなどでの制度 事例が参考になろう。

規制の中心をなす建築物の省エネ基㴶については、各国ともここ 20 年間規制を徐々に強化している中、日本でも省エネリサイクル 法の建築における基淮や省エネ法の住宅における次世代省エネ基準 は、欧米の基準にほぼ並んできている。しかし、その実効性となる

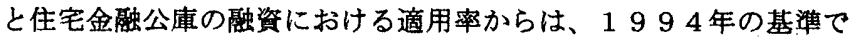
さえまだ新築の半分に達していない状況である。そこで今後は、新 基準の普及に样々な政策手法を用いて、工夫を凝らすべきである。 ここでは、ラベル制度などの各国の情報政策が参考になろう。また 財政上困難かもしれないが、産業部門や他のＯEＣD諸国で探って いる税制上の優遇措置や補助もあわせて検討するべきであろう。

なお、欧州で規制対象となっている既存建築物への断熱措直につ いては、日本ではまだ技術的に課題が多いが、モデルプロジェクト などを活用して技術開発を開始しておく時期に来ている。

\section{（规制以外の省エネ政策の訐価）}

経済政策から見た建築の省エネ対策の課題としては、「建築部門 では省エネを行らことによる大きな利益が、その設計者や建物所有 者に邆元されにくい市場構造になっている。よいう指摘がある。 そこで、省エネ建築に対する更なる税制優遇措置、エネルギ一価格 の優遇及び建築物利用者に還元されている利益が明示されるよう、 コストを含む省エネ性能の表示法の開発が期待される。

また、日本では公害防止対策で活用されている自主政策を建策の 省エネに適用することを検討する必要ある。例えば、次世代省エネ 基準の達成を宣言し（公庫や政府と協定し）た企業に対して融资や 税などの優遇措圈を講じるという仕組みがありうる。

技術政策に関しては、環境と情報が政府全体の研究・技術開発の 重点目標になっている中で、建築分野での省エネに関するライフサ イクル分析手法、高効率換気システムなど先導的技術への総合的な 取組みが肝要である。ここでは、欧米との共同研究が期待される。 もちろん、技術の普及に関しても、情報政策の中で使いやすいガイ 
ドラインや具体の简易工法を開発する努力が、業界団体、職能団体 に求められる。また、そのための政府の支援策も必要であろう。

\section{（2）沮暖化防止に関する政策の拜伍}

日本の温暖化防止対策は、総論ではどこにも反対はない。このた め、その努力義務をうたった（世界で初めての）温暖化防止に関す る法律は昨年、京都会議を主催した日本で成立している。

しかし、具体に各業界や家庭に数値目標を示し、何らかの義務を 䂺すまでには至っていない。これは、景気が不透明な時期であるこ と、具体に目標を監視する手段が（エネルギー使用量以外に）ない ことなどが理由である。さらに、国際的な枠組みでも排出権取引、 クリーン開発メカニズム、森林における温暖化ガスの吸収の算定方 法なとが議睮中であることも影響している。

日本における京都目標の達成は、表 1 の中段にある 1995 年ま での 5 年間の実績值で比較して分かる通り、米国、カナダと並んで 非常に颜しい状況にある。そこで、今後目標の 2010 年が迫るに つれ、規制政策を導入する必要が高まることが十分に予想される。

建築部門では、温暖化防止対策はほぼ省エネ対策と重なることか ら、前記の省エネ政策を環境政策と連動させて強化することが第 1 である。また、化石然料から再生可能エネルギーへの転換を進める ため、風力や太陽光発電を推進したり、化石燃料の利用効率を高め るため、コージェネレーションの建築への適用を推進していくこと も重要な課題である。再生可能エネルギーの普及推進政策は 3 例だ け挙げられているが、今後、I E Aなどと共同でワークショップや 調査を行う過程で、さらに政策研究を進めたい。

\section{7. 結䁬}

エネルギー政策は、供給対策と需要対策からなっているが、この うち需要側の最大の踝題がエネルギーの効率的利用と効用を磪保し ながらのエネルギー使用量の削減（環境勃率や資源効率の向上）て ある。中でも取組みが遅れているといわれている建築・住宅部門は、 産業部門、交通部門と並び重要な分野である。今後、先進国 $(\mathrm{OE}$ $\mathrm{CD}$ 諸国）では地球温暖化防止対策の中で、エネルギーの有効利用 がエネルギー政策の枠を超えて、ますます重要な政策課題になりつ つある。

建築のエネルギー対策は、現状でも OE C D諸国の建築における 理境対策のおよそ半分を占めている。環境に関する施策は、今後も あらゆる政策部門で増加することも加味すると、建築政策の中でも 省エネと再生可能エネルギーの利用を含む温暧化防止は、連動した 重要課題として充実していくべき分野である。

具体の政策手法は、規制、自主的取組み、経済手段、情報、研究 技術開発と梯々である。本論では、なぜ他の建築における㻴境対策 と比較して规制政策がエネルギー分野では取られていないのか、ま た、規制以外の政策の中でどのような政策がエネルギー対策を進め るのに効果的であるかについて分析を行った。

それぞれの政策手法について、その特徽と限界を理解した上て、、 各国の実情に応じた政策を開発していくことが望まれる。その際、 OE C Dのサステナブル建笨プロジェクトなどを通じての国祭的な 情報交換や政策の比較検討が、日本に対しても有効な示唆を与えて くれるであろう。)

\section{8. 徱辞}

本研究は、OECDのサステナブル建築プロジェクトを御指導頂 いている東京大学の村上周三教授のご指導により、まとめることが できました。本論の作成にあたり、想切なご指導を頂いた村上先生 に深く即意を表します。

\section{劫考文塥}

\section{(IEA / OECD 関係)}

1. IEA: Energy Balance of OECD Countries 1995-1996

2. OECD: Climate Change, March 1999

3. IEA: Energy Policies of IEA Countries, Standard Reviews, June 1998

4. OECD: Sustainable Building Policy: Summary Report of 16 OECD Member Countries and the European Commission, Oct. 1999

IEA: Energy Prices of OECD Countries, 1996

6. OECD : Sustainable Building, November 1998

7. IEA: Capital Stock Turnover Rates, Feb 1998

8. IEA: Energy Efficiency Initiatives, Feb. 1998

9. IEA: Energy Efficiency Indicators and Technology Change, Feb. 1998

10. IEA: World Energy Prospect to 2020, Apr 1998

11. IEA: IEA Implementing Agreements in a Post-Kyoto World, May 1998

12. IEA: Country Reviews, Summary presentation of key conclusions and recommendations, May 1998

13. IEA: Energy Policies of IEA Countries - Standard Reviews, July 1998

14. IEA: IEA Activities in Technology Transfer and Deployment, Nov. 1998

15. IEA: Draft Report of Japan, Nov. 1998

16. IEA: CERT Programme of Work for 1999, 1998

17. IEA: Sectoral Energy Policy Package and a Comprehensive Approach to Climate Change Responses, 1998

18. IEA: Energy R\&D Trends, May 1998

19. IEA: Energy Efficiency; The role of Prices \& Technology Development, June 1999

20. IEA: CO2 Emissions from Fuel Combustion 1971-1996, 1997

21. IEA: Indicators of Energy Use and Efficiency, 1997

22. OECD: OECD Sustainable Consumption and Production Program, Feb. 1998

23. OECD: Energy Efficiency Standarde for Traded Products, Aug. 1998 (その他の参考文献)

24. ECEEE: Energy Efficiency and $\mathrm{CO} 2$ reduction, (European Council for an Energy-Efficient Economy), 1999

25. 謤境庁地球環境部：地球温䁔化防止対策ハンドブック、民生螎、地球 温㖟化対策技衍評価検討会報告 1992 年

26. (时) 㻓境調查センター：季刊環境研究、特集・地球温瞹化対策関連法 制の国際比較、1996 年 No.101

27. 啸学会地球桭境委員会サステナブルビルディング小委員会、サステ ナフルビルディング普及のための提霄、1999 年 3 月

28. 建設省官庁営縉部、（社）公共建築協会、グリーン庁含計画指針及び同 解説、1999 年

(注)

1) エネルギー消費については、IEA の Energy Balance of OECD Countries (1995-1996) で、火力発電所を中心とする雨力部門で消费されるエネルギ 一も最終消费先となる産莱部門や建築・住宅部門に振り分けられているが、

二酸化炭菜の排出については、IEAのCO2 Emissions from Fuel Combustion

(1971-1996) のデータでは、電力部門が独立した部門となっており、最終 雼要者別の内征は示されていない。

2) OECD の Climate Change (March 1999) による。COP 3 では、29 ある O E C D加盟国のうち、軲国、トルコ、メキシコの3r国で温暖化ガス の能減目標が定められていない。

3) IEAのエネルギー政策審查垠告青（日本 1999 年、米国 1998 年、英国 1998 年、ベルギー1997 年、カナダ 1997 年) では、各国でエネルギー消费部門の 分類方法が異なっており、英国では、発電時に必要なエネルギーを電力部門 として計上している。この中には、建策物内で使用される電力分が含まれて いる。なお、表 2 のヶ国の $\mathrm{CO}_{2}$ 削诚目標数值は、原本においても単位が 異なっている。

4) OECD $の$ Sustainable Building Policy: Summary Report of 16 OECD Member Countries and the European Commission (Oct. 1999、安藤作成) の図 2 及び图 4 より引用。

5) IEA の Energy Prices of OECD Countries 1996 のテータをもとに安藤 が作成。

6) OECD $の$ Sustainable Building（November 1998）のほか、上記注 4 の 文献㗄料、今後 IEA での建勧政策分野における展開なとがある。 